\title{
Response of micro-algae in the Kromme Estuary to managed freshwater inputs
}

\author{
Snow GC and Adams JB* \\ Botany Department, Nelson Mandela Metropolitan University, PO Box 77000, Port Elizabeth 6031, South Africa
}

\begin{abstract}
The Kromme is a permanently open estuary that receives little freshwater input because the capacity of the dams is equivalent to the mean annual runoff from the catchment. The estuary is marine dominated and phytoplankton chlorophyll $a$ is low because of the low freshwater pulses that introduce nutrient-rich freshwater. Water released $\left(2 \times 10^{6} \mathrm{~m}^{3}\right)$ from the Mpofu Dam in 1998 produced little micro-algal response in the estuary. The study reported here addresses further runoff scenarios to see which might be beneficial in stimulating microalgal production. Recent surveys together with past research were used to describe the present state and reference condition of the estuary. Average intertidal chlorophyll $a$ was $12.9 \pm 2.5 \mu \mathrm{g} \cdot \mathrm{g}^{-1}$ of sediment and $4.9 \pm 0.4 \mu \mathrm{g} \cdot \mathrm{g}^{-1}$ of sediment during November 2003 and July 2004. These concentrations are relatively low but comparable to those found in intertidal sediments in other South African estuaries and might indicate that intertidal microalgal biomass is not severely limited by low freshwater inputs. Average water column chlorophyll $a$ concentrations have ranged from $0.6 \pm 0.1$ to $5.6 \pm 0.3 \mu \mathrm{g} \cdot \ell^{-1}$. Present state conditions can thus be described as those where water column chlorophyll $a$ seldom exceeds $5 \mu \mathrm{g} \cdot \ell^{-1}$ and small flagellates $(3.5 \mu \mathrm{m} \times 2.8 \mu \mathrm{m})$ dominate the phytoplankton. The diatoms introduced via freshwater have been lost. Under reference conditions before the Mpofu Dam was built, baseflow would have been greater than $1 \mathrm{~m}^{3} \cdot \mathrm{s}^{-1}$ for approximately 8 months of the year. The flocculation of fine particles associated with the mixing of fresh and saline waters would have resulted in phytoplankton peaks ( $\left.\operatorname{chl} a>10 \mu \mathrm{g} \cdot \ell^{-1}\right)$ in the middle reaches of the estuary. A more suitable habitat might also have been present for the epipelic (mud associated) benthic microalgae. An assessment of the future runoff scenarios indicated that the most beneficial for the microalgae would be a flow release from the Mpofu Dam of $5 \times 10^{6} \mathrm{~m}^{3}$ in October and then again in January. This would stimulate a 25 to $33 \%$ increase in phytoplankton chlorophyll $a$ and a doubling in intertidal benthic chlorophyll $a$ for a period of two months following the releases.
\end{abstract}

Keywords: phytoplankton, microphytobenthos, freshwater inflow, salinity, present state, dam releases

\section{Introduction}

The Kromme Estuary is located in the Eastern Cape Province, $80 \mathrm{~km}$ west of Port Elizabeth. The estuary is relatively narrow with an average width of approximately $80 \mathrm{~m}$, and extends for $14 \mathrm{~km}$ from the permanently open mouth to a rocky sill that forms the tidal head of the estuary. Its major tributary is the Geelhoutboom River which enters $8 \mathrm{~km}$ from the mouth. The catchment area and length of the Kromme River are approximately $1000 \mathrm{~km}^{2}$ and $100 \mathrm{~km}$ respectively. The rainfall in the catchment occurs throughout the year, with bimodal maxima in autumn and spring. January and February tend to have the lowest rainfall (Bickerton and Pierce, 1988).

There are two dams above the estuary and their combined holding capacity (Mpofu Dam $107 \times 10^{6} \mathrm{~m}^{3}$ and the Churchill Dam $33.3 \times 10^{6} \mathrm{~m}^{3}$ ) exceeds the mean annual runoff (MAR) of the Kromme River (estimated to be in excess of $105 \times 10^{6}$ $\mathrm{m}^{3}$ ) (Reddering, 1988). This has resulted in the water becoming saline towards the head of the estuary. In addition to reduced river flow, the dams have also affected the frequency and magnitude of flood events, and the availability of riverine material replenishing the estuarine nutrient pool (Scharler et al., 1997). A release policy, which provides $2 \times 10^{6} \mathrm{~m}^{3} / \mathrm{a}$ (EMATEK (CSIR) 1994), was proposed to account for the evaporative loss of the estuary (Jezewski and Roberts, 1986). However, flow

* To whom all correspondence should be addressed.

용 +2741 5042429; fax: +2741 5832317;

e-mail: janine.adams@nmmu.ac.za

Received 21 July 2005; accepted in revised form 17 November 2005. records and personal communications with the Mpofu Dam managers indicate that very few or no releases have been made for a number of years (2002 to 2005). The construction of farm dams and abstraction of water for agriculture have significantly reduced the flow of water from the Geelhoutboom River.

A freshwater release study in 1998 (Bate and Adams 2000; Snow et al., 2000a) indicated that a release of $2 \times 10^{6} \mathrm{~m}^{3}$ had little beneficial effect on the estuary and that a consistent baseflow was probably necessary to maintain water column production. The results reported in this study were a component of a Department of Water Affairs and Forestry comprehensive Ecological Reserve study on the Kromme Estuary. The response of the micro-algae to different runoff scenarios was investigated to compare which would be most beneficial to micro-algal production.

The aims of this study were to document the present state of micro-algae (phytoplankton and microphytobenthos) in the Kromme Estuary, determine how this has changed from the reference condition (before anthropogenic influences) and then to predict changes in response to varying freshwater inflow scenarios. The present status assessment was based on two recent surveys and past research results. The freshwater inflow scenarios considered were:

- $5 \times 10^{6} \mathrm{~m}^{3}$ release from the Mpofu Dam during November

- $5 \times 10^{6} \mathrm{~m}^{3}$ release during November and another in January

- Maintain present flow in the Kromme but increase flow in the Geelhoutboom Tributary

- $5 \times 10^{6} \mathrm{~m}^{3}$ release during November and increased flow from the Geelhoutboom Tributary

- $7.5 \times 10^{6} \mathrm{~m}^{3}$ release over a two-month period (OctoberNovember). 


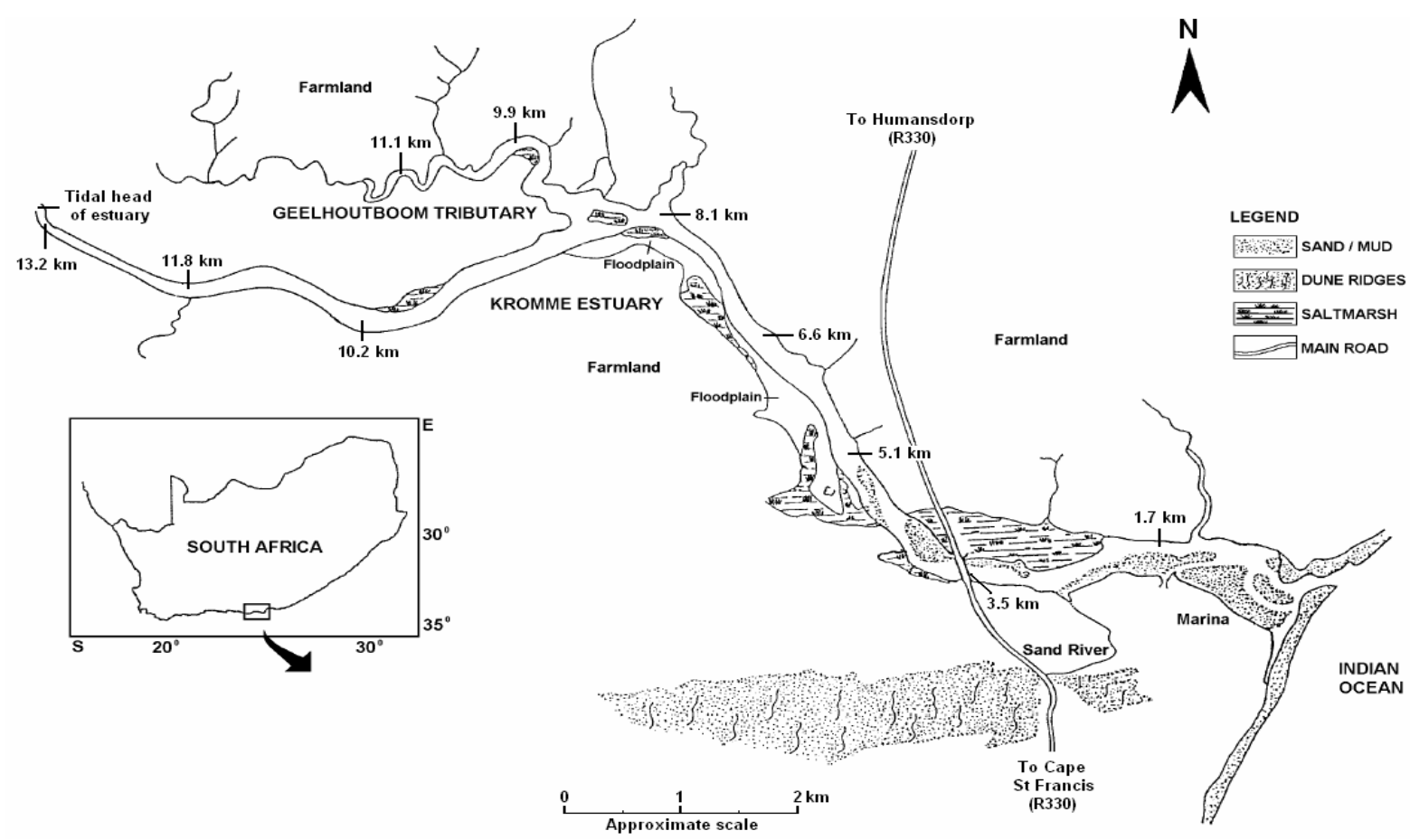

Figure 1

Map of the Kromme Estuary and Geelhoutboom Tributary, showing distances of the sampling stations (km from the mouth) for the 2004 surveys (modified from Bickerton \& Pierce, 1988)

\section{Materials and methods}

\section{Study site}

The Kromme Estuary occurs in a relatively undisturbed and pristine area. It meanders through rural land and there is little urban, industrial and agricultural development in the area (Baird and Heymans 1996). Recently there has been a lot of clearing along the banks of the estuary associated with recreational/residential developments. A road bridge, constructed in 1979 , crosses the estuary approximately $3 \mathrm{~km}$ from the mouth and a marina development consisting of a number of canals with waterfront housing and mooring facilities is located on the west bank near to the mouth (Emmerson et al., 1982). The substrate at the mouth area varies between medium- and coarse-grained sand with some silt. In the lower and middle reaches, mud and silt are encountered whereas the substrate of the upper reaches consists of coarse silty sand, stones and rocks.

The estuary was sampled for micro-algae in November 2003 and in July 2004. These surveys focused on the Geelhoutboom Tributary where previously little data existed. Samples were collected at similar locations to sites used by Scharler et al. (1997) (Fig. 1). During November 2003, two sampling sites were located below the confluence of the Kromme Estuary and the Geelhoutboom Tributary, 1.7 and $8.1 \mathrm{~km}$ from the mouth, and two sites were located within the Geelhoutboom, 9.9 and $11.1 \mathrm{~km}$ from the mouth. An additional site was located near to the head of the estuary but only physico-chemical measurements were taken there. On 30 July 2004 there were 10 sites in total, all matching the locations of Scharler et al. (1997). Sites at 1.7, 5.1, 6.6, 8.1, $10.2,11.8$ and $13.2 \mathrm{~km}$ from the mouth closely match the sites sampled during the 1998 freshwater release study (Snow et al., 2000a).

\section{Physico-chemical factors}

Physical parameters (conductivity, salinity, dissolved oxygen content, total dissolved solids, temperature, redox potential (ORP) and $\mathrm{pH}$ ) were measured using a 650 MDS YSI multiprobe. Measurements were taken every $0.5 \mathrm{~m}$ from the surface at each site. Light attenuation through the water column was measured with a Secchi disc and determined as described by Dawes (1981): $\mathrm{K}\left(\mathrm{m}^{-1}\right)=(1.7 / \mathrm{secchi}$ depth).

\section{Phytoplankton biomass}

Water column samples were collected from the surface and bottom and then gravity-filtered through plastic Millipore towers using Whatman $(\mathrm{GF} / \mathrm{C})$ glass-fibre filters (Snow et al., 2000a). The samples were collected using a $500 \mathrm{ml}$ weighted pop-bottle. Chlorophyll $a$, used an index of phytoplankton biomass, was extracted by placing the filters into glass vials containing $10 \mathrm{ml}$ of $95 \%$ ethanol (Merck 4111). The samples were then stored overnight at 1 to $2^{\circ} \mathrm{C}$. The contents of the vials were filtered and the light absorbance at $665 \mathrm{~nm}$ of the supernatant was determined using a spectrophotometer within $24 \mathrm{~h}$, before and after the addition of $0.1 \mathrm{~N} \mathrm{HCl}$. The equation used was that of Hilmer (1990), derived from Nusch (1980):

Chlorophyll $a$ biomass $\left(\mu \mathrm{g} \cdot \ell^{-1}\right)=\left(\mathrm{E}_{\mathrm{b} 665}-\mathrm{E}_{\mathrm{a} 665}\right) \times 29.6 \times(\mathrm{v} /(\mathrm{V} \times 1))$

where:

$\mathrm{E}_{\mathrm{b} 665}=$ absorbance at $665 \mathrm{~nm}$ before acidification

$\mathrm{E}_{\mathrm{a} 665}=$ absorbance at $665 \mathrm{~nm}$ after acidification

$\mathrm{v}=$ volume of solvent used for the extraction $(\mathrm{m} \ell)$

$\mathrm{V}=$ volume of the sample filtered $(\ell)$

$\mathrm{L}=$ path of spectrophotometer cuvette $(\mathrm{cm})$ 
$=$ constant calculated from the maximum acid ratio (1.7) and the specific absorption coefficient of chlorophyll-a in ethanol $\left(82 \mathrm{~g} \cdot \ell^{-1} \cdot 10 \mathrm{~mm}^{-1}\right)$

\section{Microphytobenthos biomass}

Benthic chlorophyll $a$ was used as an index of microphytobenthic biomass ( $\mu \mathrm{g}$ chl- $a$ per gram of freeze-dried sediment; expressed as $\left.\mu \mathrm{g} \cdot \mathrm{g}^{-1}\right)$. The method is a combination of techniques described in Dalsgaard et al. (2000) and Snow et al. (2000a). Four $10 \mathrm{~mm}$ deep intertidal and subtidal sediment cores were collected from each site, then frozen and kept in the dark before being freeze-dried in the Secfroid Lausanne Suisse freeze-drier. The process of freeze-drying eliminates the error related to the water holding capacity of different sediment types and organic content. Once freeze-dried, $4 \mathrm{ml}$ of $95 \%$ ethanol (Merck 4111) was added to approximately $100 \mathrm{mg}$ of sample and the pigment was left to extract in a fridge at $\sim 4^{\circ} \mathrm{C}$ for $24 \mathrm{~h}$.

After extraction the samples were well mixed using a whirl-mixer $(\mathrm{WM} / 250 / \mathrm{SC} / \mathrm{P})$ and the extract injected into a high performance liquid chromatograph (HPLC) attached to Waters-Lambda-Max 481 LC spectrophotometer and Waters LM-45 solvent delivery system for chlorophyll $a$ analysis. An HPLC was used to analyse benthic chlorophyll $a$ because sediment generally contains high concentrations of phaeo-pigments, break-down products of chlorophyll $a$, which interfere with the absorption peak when using a spectrophotometer. A 30\% methanol and $70 \%$ acetone mixture was used as a carrier. The system was calibrated using the chlorophyll $a$ of red seaweed, (Plocamium corallorhiza (Turner) Harvey) because it contains no chlorophyll $b$ that might interfere with the chlorophyll $a$ reading. Chlorophyll $a$ absorbance was measured at $665 \mathrm{~nm}$. The chlorophyll $a$ concentration was determined from the absorbance reading using the modified equation of Nusch (1980):

$$
\begin{aligned}
& \text { Chl- } a \text { biomass }\left(\mu \mathrm{g}^{-1} \mathrm{~g}^{-1}\right)=\left[\left(\left(\mathrm{E}_{\text {Ploc665 }}-\left(\mathrm{E}_{\text {Ploc665 }} / 1.7\right)\right) \times 29.6\right]\right. \\
& \times(\mathrm{V} / \mathrm{M}) \times \mathrm{E}_{H P L C}
\end{aligned}
$$

where:

$\mathrm{E}_{\text {Ploc665 }}=$ Plocamium collorhiza chlorophyll $a$ absorbance measured using the spectrophotometer at 665 $\mathrm{nm}$ (calibration formula in squared brackets)

$29.6=$ constant calculated from the maximum acid ratio (1.7) and the specific absorption coefficient of chlorophyll $a$ in ethanol $\left(82 \mathrm{~g} \cdot \ell^{-1} \cdot 10 \mathrm{~mm}^{-1}\right)$

$\mathrm{V}=$ volume of ethanol used to extract pigment $(\mathrm{ml})$

$\mathrm{M} \quad=$ mass of freeze-dried sample $(\mathrm{g})$

$\mathrm{E}_{\mathrm{HPLC}}=$ HPLC absorbance value

\section{Protista identification}

Surface and bottom water ( $500 \mathrm{ml}$ each) were collected for 'phytoplankton' identification and preserved with one millilitre of $25 \%$ glutaraldehyde solution (Sigma Chemicals G 5882). Two drops of Rose Bengal (Sigma Chemicals R 3877) were added to $60 \mathrm{ml}$ of the preserved water samples and poured into a 26.5 $\mathrm{mm}$ internal diameter Utermohl settling chamber. The cells were left to settle for $24 \mathrm{~h}$ before identification with a Zeiss IM 35 inverted microscope at the maximum magnification of $\mathrm{X}$ 630. Two hundred cells were counted in each sample and the cells were classified according to different groups; i.e. small flagellates, large flagellates, diatoms, dinoflagellates, cyanobacteria, chlorophytes, euglenoids and coccolithophorids (Snow, 2000). Data were only available for the November 2003 survey.
A number of euglenoids and flagellates do not contain photosynthetic pigments (Mauseth, 1994). They are categorised as heterotrophs and zoologists regard this group as protozoans. As a result, the groups considered in this study (excl. cyanobacteria) were classified under Protista and not as phytoplankton. Cyanobacteria (Kingdom Monera) that were easily recognisable under the inverted microscope were included into the study as their presence could be indicative of low oxygen concentration.

\section{Nutrients}

Nitrate concentration was determined using the reduced coppercadmium method described by Bate and Heelas (1975). Nitrate was collected from surface and bottom water at each site using a weighted pop-bottle. The nitrate in the filtered (Whatman GF/ $\mathrm{C}$ filters) water samples was reduced to nitrite then determined as $\mathrm{NO}_{2}^{-}-\mathrm{N}$ plus $\mathrm{NO}_{3}^{-}-\mathrm{N}$. Nitrite was quantitatively incorporated into a diazo-couple (red/purple) compound and then the concentration determined at $540 \mathrm{~nm}$ using a GBC UV-VIS spectrophotometer. All results were expressed in $\mu$ Molar values as these units obviate any problems of interpretation between $\mathrm{N}$ and other oxidised nitrogen (NOx) compounds.

\section{Ash free dry weight (AFDW) and water content (WC) of the sediment}

Three surface sediment samples were taken from intertidal and subtidal zones to a depth of $10 \mathrm{~mm}$. Once in the laboratory, the wet sediments were weighed and placed into pre-dried $(24 \mathrm{~h}$ at $105^{\circ} \mathrm{C}$ ) and pre-weighed crucibles. The sediments were dried in the oven for $24 \mathrm{~h}$ at $105^{\circ} \mathrm{C}$ and were weighed again (dry weight). The crucibles were placed into a furnace at $550^{\circ} \mathrm{C}$ for $1 \mathrm{~h}$ and were weighed again (ash weight).

\section{Statistical analyses}

The Student's t-test and one-way ANOVA (Tukey's Multiple Comparison Test) were used to compare different sampling sites for significant differences. The Kolmogorov-Smirnov test was used to test the data for normality and the Mann-Whitney Rank Sum test was used to test non-parametric data for significant differences. Pearson's correlation coefficient, with a $0.05 \alpha-$ level, was used as a measure of strength of linear relationships between variables. Statistical tests were performed using the Statistica 7 (StatSoft, Inc.) software package.

\section{Results and discussion}

\section{July 2004}

Results indicate that water quality and micro-algal chlorophyll $a$ remained relatively constant throughout the Kromme Estuary and Geelhoutboom Tributary. There was a decrease in temperature, electrical conductivity (EC) and redox potential (ORP) from the mouth to the head of the Kromme Estuary (Fig. 2), suggesting that there was a weak freshwater input at the head of the estuary and up the Geelhoutboom Tributary. EC was particularly low in the Geelhoutboom Tributary, $11.1 \mathrm{~km}$ from the mouth $\left(41.1 \mathrm{mS} \cdot 10 \mathrm{~mm}^{-1}\right)$. Factors such as salinity, total dissolved solids (TDS), $\mathrm{pH}$ and turbidity remained relatively constant throughout the estuary with just a slight decrease at the site nearest to the head of the estuary. Salinity, TDS and $\mathrm{pH}$ were lowest in the Geelhoutboom Tributary, $11.1 \mathrm{~km}$ from the mouth (35\%, $34.5 \mathrm{~g} \cdot \ell^{-1}$ and 8.15 respectively). In contrast, turbidity and 

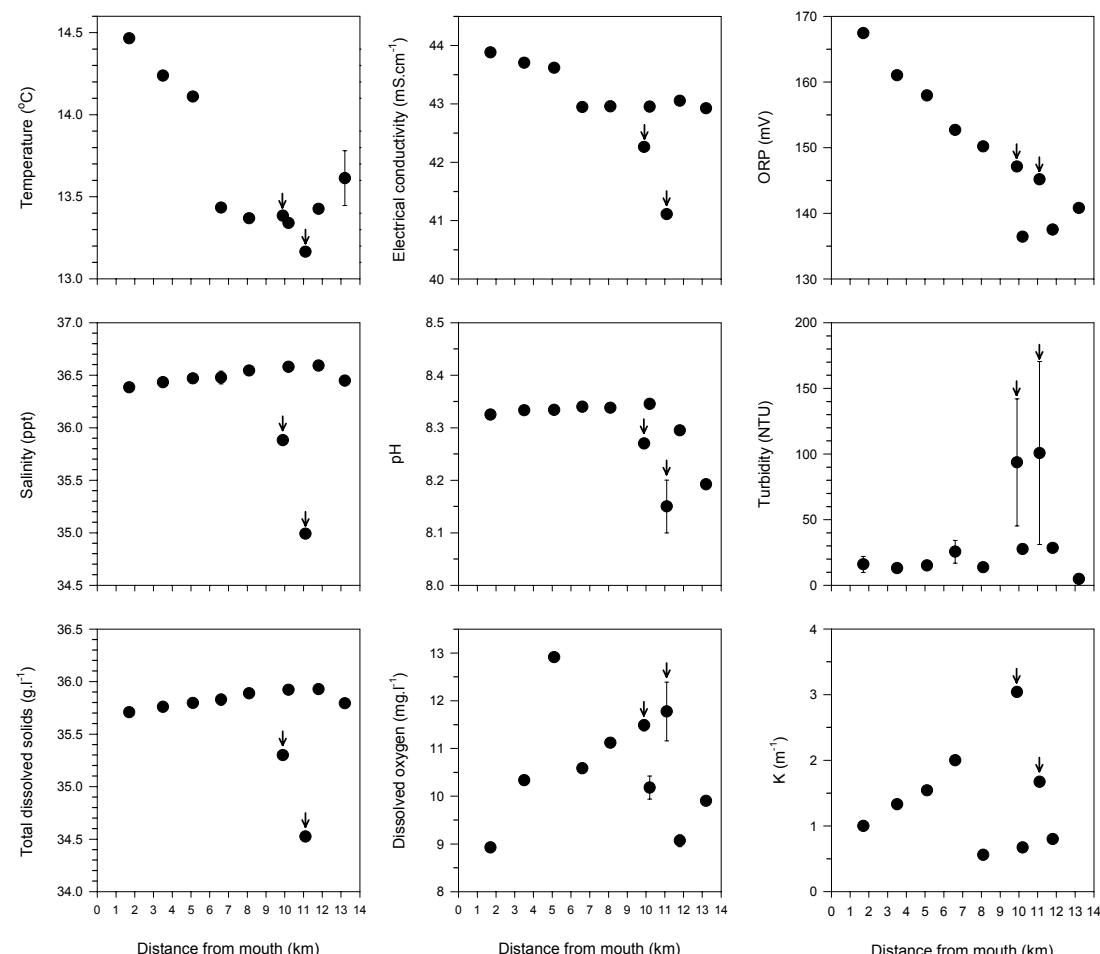

Distance from mouth $(\mathrm{km})$

light attenuation through the water column were highest in the Geelhoutboom, with maxima of 100.7 NTUs and $3.0 \cdot \mathrm{m}^{-1}$ respectively. Statistical analyses found a significant decrease in temperature (Pearson's coefficient $=-0.82 ; \mathrm{P}<0.05$ ) and EC (Pearson's coefficient $=-0.66$; $\mathrm{P}<0.05)$ with increasing distance from the mouth of the estuary. Salinity was significantly correlated to total dissolved solids (TDS) (Pearson's coefficient $=1.0$; $\mathrm{P}<0.01$ ) and $\mathrm{pH}$ (Pearson's coefficient $=$ $0.75 ; \mathrm{P}<0.05$ ), which suggests that the majority of TDS was made up of salts and this determined the $\mathrm{pH}$ of the water in the estuary.

Phytoplankton chlorophyll $a$ remained relatively constant throughout the estuary with only a slight decrease at the site nearest to the head of the estuary. The highest average phytoplankton chlorophyll $a$ was $5.0 \pm 1.5(\mathrm{n}=2), 9.9 \mathrm{~km}$ from the mouth in the Geelhoutboom Tributary (Fig. 3), but there were no significant differences in phytoplankton chlorophyll $a$ between any of the sites. Phytoplankton chlorophyll $a$ was significantly cor-

Figure 2

Physico-chemical variables measured in the Kromme Estuary (30 July 2004) in relation to distance from the mouth. Arrows indicate measurements recorded in the Geelhoutboom Tributary. Vertical bars represent \pm SE mean.

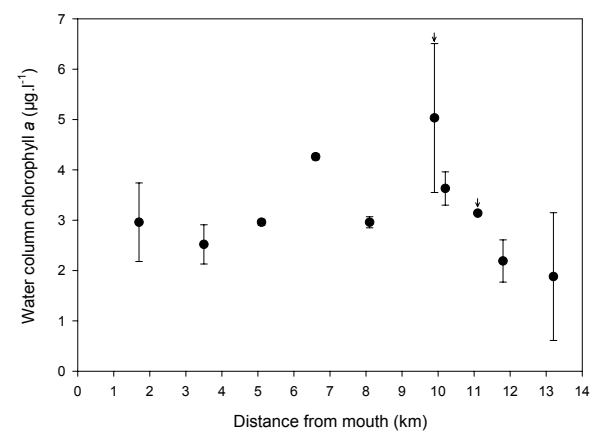

Figure 3

Water column chlorophyll a in the Kromme Estuary (30 July 2004). Arrows indicate measurements recorded in the Geelhoutboom Tributary. Vertical bars represent \pm SE mean.

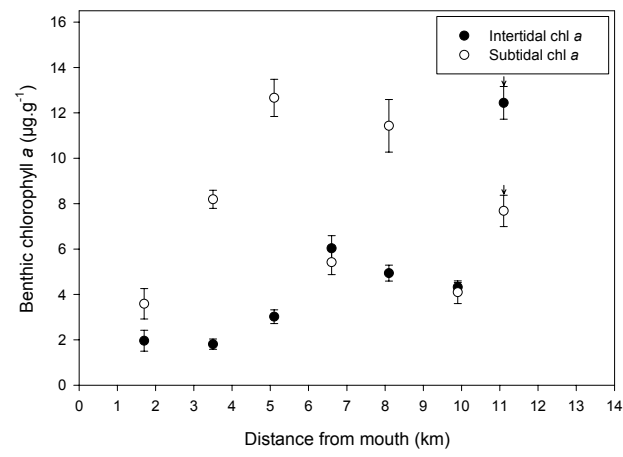

Figure 4

Intertidal and subtidal benthic chlorophyll a in the Kromme Estuary (30 July 2004). Arrows indicate measurements recorded in the Geelhoutboom Tributary. Vertical bars represent \pm SE mean.

related with light attenuation through the water column. This suggests that phytoplankton cells contributed significantly to the attenuation of light and/or were closely associated to suspended particles in the water column.

Intertidal benthic chlorophyll $a$ ranged from $1.8 \pm 0.2$ $\mu \mathrm{g} \cdot \mathrm{g}^{-1}$ to $12.4 \pm 0.7 \mu \mathrm{g} \cdot \mathrm{g}^{-1}$, showing a gradual increase from near the mouth to the Geelhoutboom Tributary, $11.1 \mathrm{~km}$ from the mouth (Fig. 4). Subtidal benthic chlorophyll $a$ was significantly higher than intertidal chlorophyll $a(\mathrm{t}=-2.81 ; \mathrm{P}<0.01$; d.f. $=54)$, and ranged from $3.6 \pm 0.7 \mu \mathrm{g} \cdot \mathrm{g}^{-1}(1.7 \mathrm{~km}$ from the mouth) to $12.7 \pm 0.8 \mu \mathrm{g} \cdot \mathrm{g}^{-1}$ (5.1 $\mathrm{km}$ from the mouth) (Fig. 4). There was no significant correlation between subtidal benthic chlorophyll $a$ and any physico-chemical factor but intertidal chlorophyll $a$ was closely associated to salinity and its covariables (TDS and $\mathrm{pH}$ ). As a result intertidal chlorophyll $a$ increased from the mouth of the estuary to $11.1 \mathrm{~km}$ from the mouth in the Geelhoutboom Tributary and was highest where overlying water had the lowest EC, salinity, $\mathrm{pH}$ and temperature. This could indicate a response to freshwater input but may also be as a result of finer sediment in the Geelhoutboom Tributary.

\section{November 2003}

There was a weak longitudinal salinity gradient up the estuary (Fig. 5); water column salinity at the mouth of the estuary was $36.2 \pm 0.0 \%, 33.9 \pm 0.1 \%$ in the Geelhoutboom Tributary and $34.4 \pm 0.0 \%$ at the head of the estuary. However, both the longitudinal and vertical salinity gradients $(<2 \%$ and $<1 \%$ respectively) in the estuary were small suggesting that the water column was well mixed and that the volume of freshwater entering the estuary was low. Total dissolved solids and electrical conductivity followed a similar pattern to salinity, with ranges of 33.5 to $35.5 \mathrm{~g} \cdot \ell^{-1}$ and 51.6 to $54.6 \mathrm{mS} \cdot 10 \mathrm{~mm}^{-1}$ respectively.

Light attenuation was highest $\left(\mathrm{K}=2.8 \mathrm{~m}^{-1}\right)$ at the two sites nearest to the mouth due to the high turbulence. Lower values were found at the sites in the Geelhoutboom Tributary, $9.9 \mathrm{~km}$ 
from the mouth $\left(\mathrm{K}=2.3 \mathrm{~m}^{-1}\right)$ and at 11.1 $\mathrm{km}$ from the mouth $\left(\mathrm{K}=2.1 \mathrm{~m}^{-1}\right)$. There was no correlation found between light attenuation and depth of the water column (Fig. 5).

There was a gradual increase in water column temperature with distance from the estuary mouth; $20.5 \pm$ $0.3^{\circ} \mathrm{C} 1.7 \mathrm{~km}$ from the mouth to $24.5 \pm$ $0.3^{\circ} \mathrm{C}$ in the Geelhoutboom Tributary, $11.1 \mathrm{~km}$ from the mouth (Fig. 5).

Average phytoplankton chlorophyll $a$ was particularly low during this sampling session $\left(<1.0 \mu \mathrm{g} \cdot \ell^{-1}\right)$ and was significantly higher in the surface water compared to the bottom (Mann-Whitney; $\mathrm{T}=26.0 ; \mathrm{P}<0.05$ ). Highest chlorophyll $a$ concentration was in the surface water of the Geelhoutboom Tributary $\left(0.9 \pm 0.2 \mu \mathrm{g} \cdot \ell^{-1}\right)$, $9.9 \mathrm{~km}$ from the mouth of the estuary. Nitrate concentration was below detectable limits throughout the estuary, possibly indicating that microalgal biomass was nitrogen limited on this occasion.

Recently constructed farm dams, built within the last 10 years appears to have reduced flow entering the
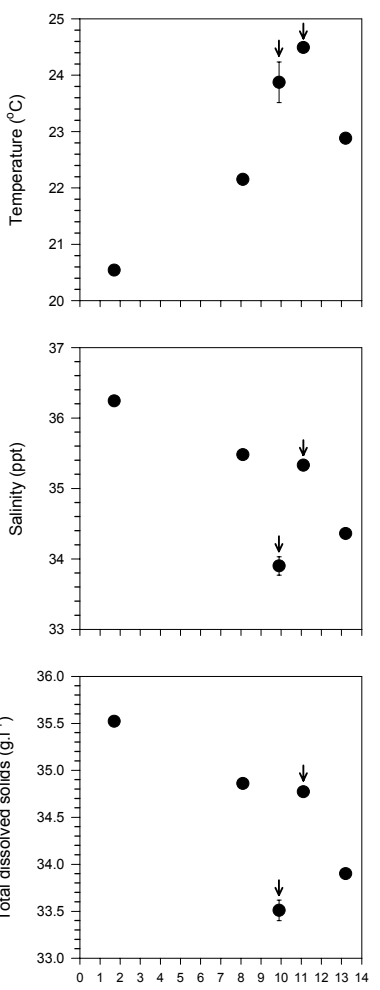

Distance from mouth $(\mathrm{km})$
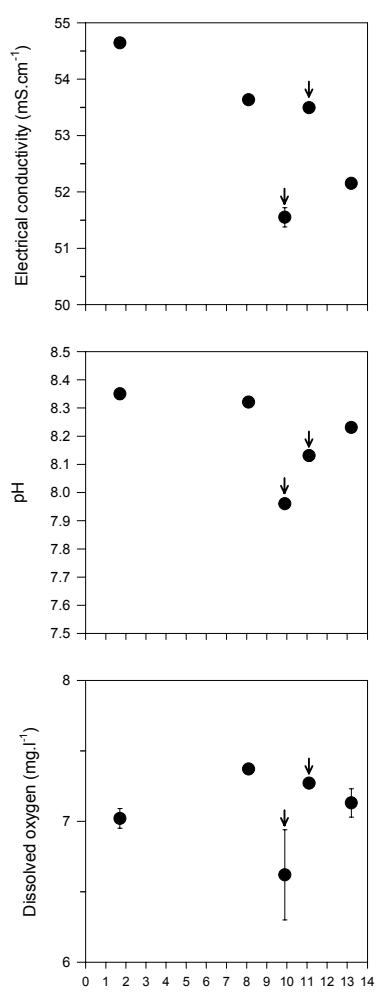

Distance from mouth $(\mathrm{km})$
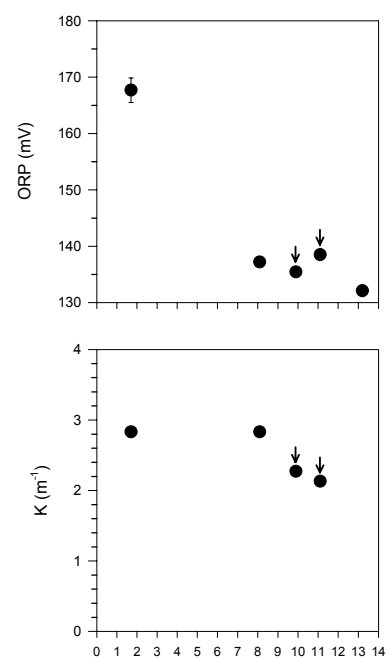

Distance from mouth $(\mathrm{km})$

Figure 5

Physico-chemical variables measured in the Kromme Estuary (24 November 2003) in relation to distance from the mouth. Arrows indicate measurements recorded in the Geelhoutboom Tributary. Vertical bars represent $\pm S E$ mean. estuary from the Geelhoutboom Tributary. During this study, salinity in the tributary was slightly lower and light attenuation slightly higher than that measured in the Kromme Estuary below the confluence (Fig. 5). This suggests that there was some freshwater input from the Geelhoutboom River and may have been the cause of the elevated chlorophyll $a$ concentrations in the surface water in the Geelhoutboom Tributary (Fig 6).

Average intertidal chlorophyll $a\left(12.9 \pm 2.5 \mu \mathrm{g} \cdot \mathrm{g}^{-1}\right)$ was significantly higher (Mann-Whitney; $\mathrm{T}=359 ; \mathrm{P}<0.001$ ) than subtidal chlorophyll $a\left(5.2 \pm 1.5 \mu \mathrm{g} \cdot \mathrm{g}^{-1}\right)$ and was particularly high at the site nearest to the mouth of the estuary $(27.1 \pm 7.0$ $\mu \mathrm{g} \cdot \mathrm{g}^{-1}$ ) (Fig. 7). Nitrate concentration was below the detectable limit throughout the estuary suggesting that intertidal benthic micro-algae were responding to an alternative source of nutrients to river water, e.g. St. Francis Marina canals or seawater. A more detailed investigation, including the canals, is recommended to confirm this.

\section{Microalgal community composition}

On 24 November 2003 flagellates were the dominant phytoplankton group. Small flagellates $(3.5 \times 2.8 \mu \mathrm{m})$ in particular had the highest relative abundance, exceeding $60 \%$ in surface and bottom water throughout the estuary and Geelhoutboom Tributary (Fig. 8). Diatoms, dinoflagellates, cyanophytes, euglenophytes, chlorophytes and coccolithophorids showed no distinct patterns in the estuary but all groups were represented in water near to the mouth of the estuary.

Phytoplankton in the Mpofu Dam, collected prior to the release of $2 \times 10^{6} \mathrm{~m}^{3}$ freshwater in November 1998 were dominated by diatoms $\left(>1500\right.$ cells $\left.\cdot \mathrm{m}^{-1}\right)$ and flagellates $(>500$ cells $\cdot \mathrm{ml}^{\ell^{-1}}$. Chlorophytes were present throughout the water column $\left(>100\right.$ cells $\left.\cdot \mathrm{m}^{-1}\right)$ but dinoflagellates were totally absent.

Phytoplankton in the Kromme Estuary during the fresh-

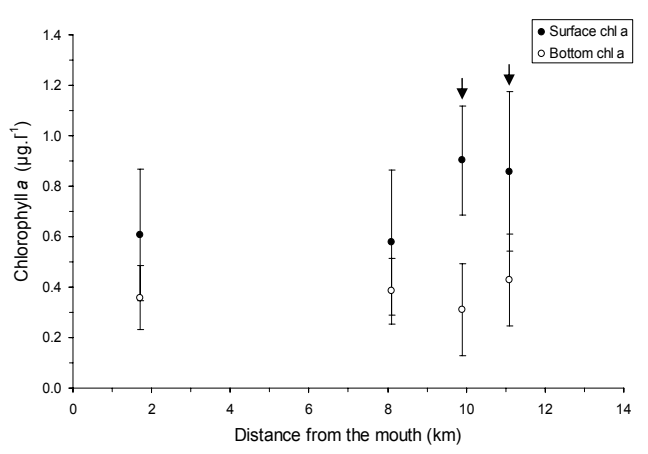

Figure 6

Water column chlorophyll a in the Kromme Estuary (24 November 2003). Arrows indicate measurements recorded in the Geelhoutboom Tributary. Vertical bars represent \pm SE mean.

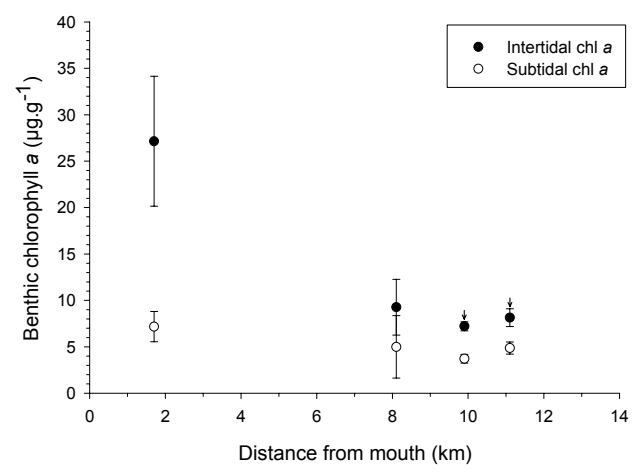

Figure 7

Intertidal and subtidal benthic chlorophyll a in the Kromme Estuary (24 November 2003). Arrows indicate measurements recorded in the Geelhoutboom Tributary. Vertical bars represent \pm SE mean. 

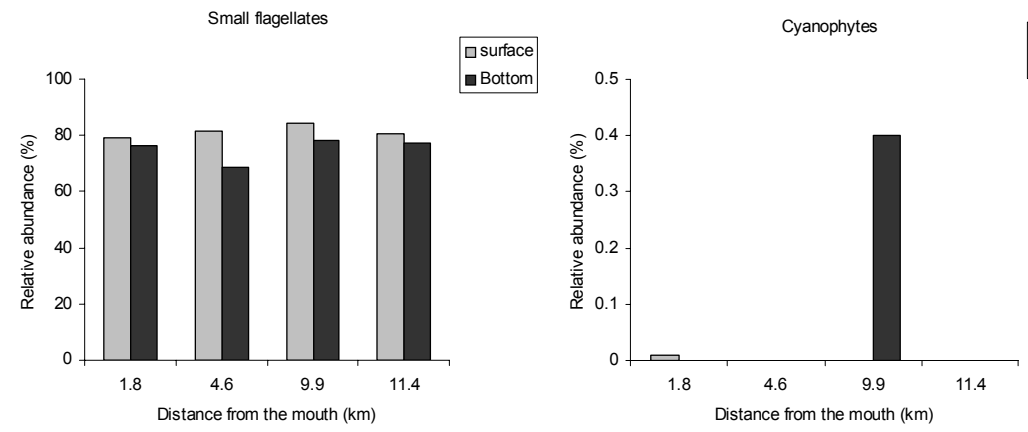

Average phytoplankton chlorophyll $a$ in the Kromme Estuary has consistently been lower than the nearby eutrophic Gamtoos Estuary (Table 1). Average concentrations in the Kromme have ranged from $0.6 \pm 0.1$ to $5.6 \pm 0.3 \mu \mathrm{g} \cdot \ell^{-1}$. Average salinity during this study (November 2003 and July 2004) was generally similar or greater than seawater and low standard error values indicate weak salinity gradients throughout the estuary. During these extended periods of low freshwater input, average phytoplankton chlorophyll $a$ has been particularly low $\left(3.0 \mu \mathrm{g} \cdot \ell^{-1}\right.$ or less). After a $2 \times 10^{6} \mathrm{~m}^{3}$ pulse of freshwater in the 1998/1999 study (Snow et al., 2000a), average chlorophyll $a$ concentration increased to a maximum of $5.6 \pm 0.3$ $\mu \mathrm{g} \cdot \ell^{-1}$, almost a month after the release.

Average intertidal chlorophyll $a$ was $12.9 \pm 2.5 \mu \mathrm{g} \cdot \mathrm{g}^{-1}$ and $4.9 \pm 0.4 \mu \mathrm{g} \cdot \mathrm{g}^{-1}$ in the Kromme Estuary during November 2003 and July 2004 of this study respectively. These concentrations are relatively low but comparable to those found in intertidal sediments in other South African estuaries, the nutrient-rich Swartkops Estuary in particular (Table 2 ), which could indicate that intertidal micro-algal biomass in the intertidal zone is not severely limited by the low freshwater inputs. However data from Snow et al. (2000a) and the microphytobenthos biomass measured in the Geelhoutboom tributary in July 2004, indicate that short term freshwater pulses can stimulate biomass possibly because of the introduction of new nutrients to the estuary.

\section{Present state}

The Mpofu and Churchill Dams have severely reduced river flow into the Kromme Estuary and flows of $<0.2 \mathrm{~m}^{3} \cdot \mathrm{s}^{-1}$ are often encountered over a number of months resulting in hypersaline conditions in the upper reaches of the estuary (CSIR, 2005). During these conditions, regarded as present state, chlorophyll $a$ in the water column seldom exceeds

water release study of 1998/1999 (Snow et al., 2000a) was dominated by flagellates prior to the release and for a few days afterwards. Up to $80 \%$ of cells were flagellates and the bulk of the remaining cells were diatoms. By the $17^{\text {th }}$ day after the release a bloom of marine coastal species (Round et al., 1990) Extubocellulus and Leptocylindrus spp. had developed resulting in diatoms becoming the dominant group with cell densities of $>11000$ cells $\cdot \mathrm{ml}^{\ell^{-1}}$ being recorded $11.8 \mathrm{~km}$ from the mouth of the estuary. The bloom was short-lived and flagellates dominated the phytoplankton by the $31^{\text {st }}$ day again.
$5 \mu \mathrm{g} \cdot \ell^{-1}$ and small flagellates dominate the phytoplankton. The diatom community introduced via the freshwater has been lost.

Table Mountain Quartzite and Bokkeveld shale occur in the Kromme River catchment (Reddering and Esterhuysen 1983). Eroded, these are sources of sand and muds but in low quantities. The high water residence time in the dams reduces sediment input to the Kromme Estuary. The Geelhoutboom River is still a source of sediment and this has resulted in the higher turbidity measured in the Geelhoutboom Tributary during this study. The reduction in flow has caused a decrease in the con- 


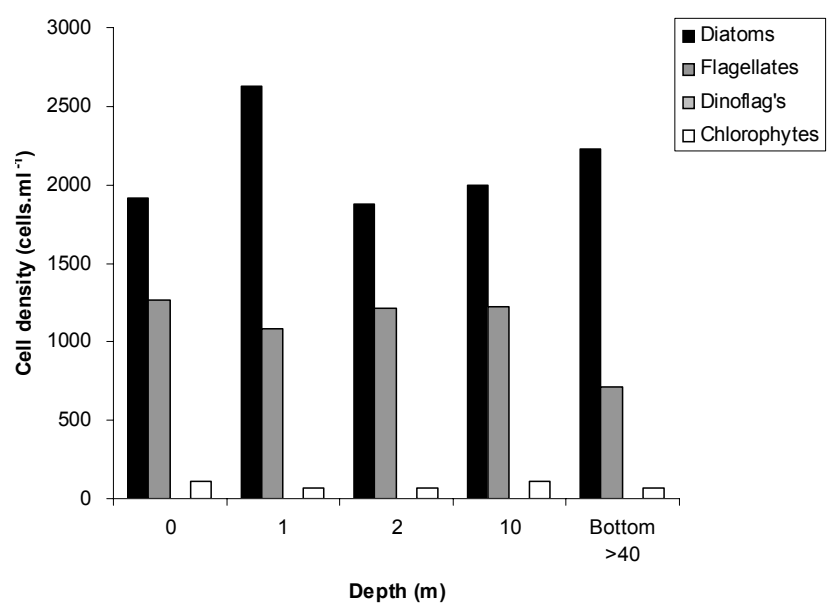

Figure 9

Cell densities of diatoms, flagellates, dinoflagellates and chlorophytes in the Mpofu Dam prior to the $2 \times 10^{6} \mathrm{~m}^{3}$ release of water (16 November 1998) (Snow et al., 2000).

centration of TSS and nutrients entering the estuary. This has reduced benthic chlorophyll $a$ concentrations although high biomass was recorded close to the mouth of the estuary $\left(20 \mu \mathrm{g} \cdot \mathrm{g}^{-1}\right)$. Average phytoplankton chlorophyll $a$ in the estuary has probably decreased by $\sim 33 \%$. The decrease would be greater but nutrient and TSS levels in the Kromme River are considered to be naturally low (Emmerson et al., 1982) and a biomass similar to the nearby eutrophic Gamtoos estuary $\left(\sim 50 \mu \mathrm{g} \cdot \ell^{-1}\right)$ is unlikely.

The Kromme Estuary is marine dominated and can be regarded as oligotrophic. Phosphate occurs in oxic sediments as the essentially insoluble Fe (III) species, but in anoxic environments iron is reduced biologically and phosphate may become solubilised. The mineralization of organic matter into ammonium and the subsequent nitrification in oxic sediment generally results in ammonium concentrations in sediment pore waters decreasing towards the sediment surface. Where there is a significant benthic oxic layer, it acts not only as a redox barrier for phosphate and iron, but also as a potential nitrification barrier for ammonium (Nedwell et al., 1999). The reduction in the frequency and intensity of freshwater pulses has reduced the number of scouring events that are required for the regeneration of 'trapped' nutrients in fine sediment within the Kromme River's catchment and estuary. Lower nutrient loads reach the estuary, reducing nutrient concentrations within the estuary, which could limit microalgal biomass.

The flocculation of TSS and nutrients during normal flow provides a suitable habitat for epipelic (mud-associated) microalgae. These micro-algae are dependent on the continual input and sedimentation of fine sediment in estuaries. Diatoms generally dominate epipelic communities. They stabilise the sediment through their carbohydrate exudates used for migration within the surface layers of the sediment (Pinckney and Zingmark, 1993; Austen et al., 1999; Miller et al., 1996). Coarser sediments (sand) are generally colonised by episammic microalgae that attach themselves to the sand particles to resist resuspension during periods of high energy (e.g. tidal currents). Fine cohesive sediments usually have a high organic matter content, with high rates of bacterial mineralization and high pore-water concentrations of dissolved nutrients, while sand-flats are more oligotrophic (Underwood and Kromkamp, 1999). Chlorophyll a or biomass of microphytobenthos in sheltered, muddy habitats is higher than that in exposed sandy habitats (MacIntyre et al.,

\begin{tabular}{|c|c|c|c|}
\hline \multicolumn{4}{|c|}{$\begin{array}{l}\text { TABLE 1 } \\
\text { Average salinity and phytoplankton chlorophyll } \\
\text { a during this study (italics) and previous studies } \\
\text { (Snow et al. 2000a\&b; Snow 2000; Scharler et al. } \\
\text { 1997) in the Kromme and nearby Gamtoos estuaries }\end{array}$} \\
\hline Estuary & Sampling date & \begin{tabular}{|l|} 
Average \\
salinity \\
$(\% \circ)$ \\
\end{tabular} & $\begin{array}{l}\text { Average phyto- } \\
\text { plankton chl a } \\
\left(\mu \mathrm{g} \cdot \ell^{-1}\right) \pm \mathrm{SE} \\
\end{array}$ \\
\hline \multirow[t]{10}{*}{ Kromme } & 24 November 2003 & $35.0 \pm 0.4$ & $0.6 \pm 0.1(n=20)$ \\
\hline & 30 July 2004 & $36.3 \pm 0.2$ & $3.0 \pm 0.2(n=36)$ \\
\hline & 16 November 1998 & $34.2 \pm 0.1$ & $4.2 \pm 1.1(\mathrm{n}=30)$ \\
\hline & 18 November 1998 & $21.5 \pm 2.1$ & $1.7 \pm 0.2(\mathrm{n}=35)$ \\
\hline & 20 November 1998 & $23.7 \pm 1.3$ & $2.1 \pm 0.2(\mathrm{n}=37)$ \\
\hline & 22 November 1998 & $29.4 \pm 0.6$ & $4.4 \pm 0.5(\mathrm{n}=27)$ \\
\hline & 3 December 1998 & $31.9 \pm 0.4$ & $4.3 \pm 0.3(n=26)$ \\
\hline & 17 December 1998 & $34.1 \pm 0.2$ & $5.6 \pm 0.3(\mathrm{n}=25)$ \\
\hline & 5 January 1999 & $35.4 \pm 0.1$ & $5.2 \pm 0.7(\mathrm{n}=25)$ \\
\hline & June 1993-June 1994 & $28.7 \pm 0.5$ & $4.2 \pm 3.3$ \\
\hline \multirow[t]{3}{*}{ Gamtoos } & 4 November 1996 & $12.5 \pm 2.1$ & $17.2 \pm 1.6$ \\
\hline & 11 February 1997 & $9.8 \pm 1.9$ & $44.8 \pm 6.1$ \\
\hline & 12 November 1996 & $10.8 \pm 2.1$ & $7.4 \pm 0.5$ \\
\hline
\end{tabular}

TABLE 2

Average intertidal chlorophyll a during this study (italics) and studies of other South African estuaries (Snow, unpublished data)

\begin{tabular}{|l|l|l|}
\hline Estuary & Sampling date & Intertidal $\mathbf{C h l} \mathbf{a}\left(\mathbf{\mu g} \cdot \mathbf{g}^{-1}\right)$ \\
\hline \multirow{3}{*}{ Kromme } & 24 November 2003 & $12.9 \pm 2.5(n=20)$ \\
\cline { 2 - 3 } & 30 July 2004 & $4.9 \pm 0.4(n=28)$ \\
\hline \multirow{2}{*}{ Kamtoos } & 7 August 2002 & $27.7 \pm 3.0(\mathrm{n}=25)$ \\
\cline { 2 - 3 } & 21 February 2003 & $10.4 \pm 0.9(\mathrm{n}=25)$ \\
\hline Mngazana & 25 August 2002 & $9.5 \pm 0.8(\mathrm{n}=25)$ \\
\hline & 22 June 2003 & $27.2 \pm 2.3(\mathrm{n}=25)$ \\
\cline { 2 - 3 } & 25 January 2003 & $16.4 \pm 2.5(\mathrm{n}=25)$ \\
\hline Sungazi & 26 January 2003 & $12.9 \pm 0.9(\mathrm{n}=25)$ \\
\hline & 19 February 2003 & $9.1 \pm 1.0(\mathrm{n}=25)$ \\
\hline Swartkops & 25 July 2002 & $10.2 \pm 1.0(\mathrm{n}=25)$ \\
\hline & 12 Fecember 2002 & $3.7 \pm 0.6(\mathrm{n}=30)$ \\
\hline & 15 August 2003 & $22.5 \pm 1.9(\mathrm{n}=30)$ \\
\hline & 28 November 2001 & $5.9 \pm 0.9(\mathrm{n}=30)$ \\
\hline & 30 October 2001 & $8.2 \pm 0.8(\mathrm{n}=30)$ \\
\hline
\end{tabular}

1996). Prolonged stable conditions would favour the dominance of only a few species thus reducing microalgal diversity

\section{Reference state}

River flow prior to the construction of dams in the catchment would have been in excess of $1 \mathrm{~m}^{3} \cdot \mathrm{s}^{-1}$ for about 8 months of the year (CSIR, 2005). The upper reaches of the estuary could have been flushed fairly regularly of high salinity water from the deep upper reaches during freshwater pulses. Dams would not have been present so the higher concentration of suspended solids would have flocculated and settled out of suspension once the fresh river water and saline estuarine water mixed. The flocculation of fine particles would result in a peak in phytoplankton chl $a\left(>10 \mu \mathrm{g} \cdot \ell^{-1}\right.$, particularly in the middle reaches of the estuary) and provide a suitable environment for epipelic microphytobenthos as well as a source of nutrients for subtidal benthic microalgae. 


\begin{tabular}{|c|c|c|}
\hline \multicolumn{3}{|c|}{$\begin{array}{l}\text { TABLE } 3 \\
\text { Proposed future run-off scenarios indicating flow releases from the Mpofu Dam and } \\
\text { the annual volume of river inflow as a percentage of the reference/natural condition }\end{array}$} \\
\hline Kromme Estuary & Geelhoutboom & $\begin{array}{l}\text { Volume } \\
\left(10^{6} \mathrm{~m}^{3} \text { annum-1) }\right.\end{array}$ \\
\hline Reference & Reference & 97 \\
\hline Present flows $\left(2 \times 10^{6} \mathrm{~m}^{3}\right.$ release $)$ & Present & 35 \\
\hline 1. Flow release of $5 \times 10^{6} \mathrm{~m}^{3}(\mathrm{Nov})$ & Present & 38 \\
\hline 2. Flow release of $10 \times 10^{6} \mathrm{~m}^{3}$ (Oct and Jan) & Present & 43 \\
\hline 3. Present flows $\left(2 \times 10^{6} \mathrm{~m}^{3}\right.$ release $)$ & Flow from Geelhoutboom River & 35 \\
\hline 4. Flow release of $5 \times 10^{6} \mathrm{~m}^{3}$ (Nov) & Flow from Geelhoutboom River & 38 \\
\hline 5. Flow release of $7.5 \times 10^{6} \mathrm{~m}^{3}$ (Oct - Nov) & Present & 41 \\
\hline
\end{tabular}

High phytoplankton biomass $\left(>20 \mu \mathrm{g} \cdot \ell^{-1}\right)$ would have been limited by the low nutrient concentrations of river water and residence time of water in the estuary. In addition, a pulse of freshwater has been shown to result in a rapid increase in mysids and copepods, which would exert grazing pressure on the phytoplankton population (Jerling and Wooldridge, 1994). A strong halocline would have existed in the middle and upper reaches of the estuary ( $>5 \mathrm{~km}$ from the mouth) so that high benthic microalgal biomass would only occur in the intertidal micro-algae (commonly reaching $>100 \mathrm{mg} \cdot \mathrm{m}^{-2}$ ). Mixing of water near to the mouth would result in high intertidal and subtidal benthic chlorophyll $a\left(>100 \mathrm{mg} \cdot \mathrm{m}^{-2}\right)$

Micro-algal diversity would be high as the phytoplankton community structure would change from one dominated by diatoms near the head of the estuary to one dominated by flagellates closer to the mouth. Dinoflagellates would also occur but only in saline water near the mouth of the estuary. Snow et al. (2000 a) showed that freshwater entering the estuary from the Mpofu Dam is dominated by diatoms ( $>60 \%$ of phytoplankton), flagellates $(\sim 30 \%)$ and also contains chlorophytes $(\sim 5 \%)$. As flow has decreased from reference to present state the community structure has changed to one dominated by small flagellates throughout the estuary.

During a recent study of the nearby Gamtoos Estuary (Snow, 2000; Snow et al., 2000b), the river-estuary interface zone (REI) was defined as the distance from the mouth of the estuary where a maximum phytoplankton chlorophyll $a$ occurred. This generally occurred where vertically averaged salinity was less than $10 \%$. The REI zone is a concept developed in estuaries with a classical "cone-shaped" bathymetry. The upper reaches are narrow and shallow and become deeper and wider towards the lower reaches of the estuary. This means that as freshwater enters an estuary, a longitudinal salinity gradient develops from $0 \%$ at the head of the estuary to marine $(\sim 35 \%)$ near the mouth. This bathymetry allows the 'fresh' water to flow over the denser saline water with gradual mixing. Chlorophyll $a$ concentration in the REI of the Gamtoos Estuary was particularly high at a flow of $1 \mathrm{~m}^{3} \cdot \mathrm{s}^{-1}$ or residence time of 3 tidal cycles $(42 \mathrm{~d})$. In the case of the Kromme Estuary, the bathymetry is reversed (i.e. shallow at the mouth and deepest at the head of the estuary). The large volume of water in the upper reaches of the estuary probably limits the effectiveness of freshwater input in reducing salinity unless the input was over an extended period. The CSIR (2005) have shown that a persistent flow of 4 to $8 \mathrm{~m}^{3} \cdot \mathrm{s}^{-1}$ would scour saline waters from deeper areas in the upper reaches of the estuary but residence time would only be 3 to $7 \mathrm{~d}$. This residence time would be insufficient for a high phytoplankton biomass to develop. If it were possible for an REI zone to develop, phytoplankton biomass would still be limited by the naturally low concentration of nutrients and suspended particles in the river water.

\section{Comparison of proposed future runoff scenarios}

A number of future runoff scenarios (Table 3) were considered in the comprehensive assessment of the ecological reserve of the Kromme estuary (CSIR, 2005). The predicted response of the microalgae to the different runoff scenarios is discussed.

Scenario 1 would consist of a flow release of $5 \times 10^{6} \mathrm{~m}^{3}$ from the Mpofu Dam in November (Table 3). The month of November was chosen for the release as the establishment of a longitudinal salinity gradient will act as a cue for fish migration into the estuary which mainly occurs in late spring/summer. However for 11 months of the year, the flow will be similar to the present state, i.e. no or very little flow. As a result, there will be no or very limited mixing of freshwater with estuarine water and microalgal response would be limited. Average benthic $\left(<50 \mathrm{mg} \cdot \mathrm{m}^{-2}\right)$ and phytoplankton chlorophyll $a\left(\sim 5 \mu \mathrm{g} \cdot \ell^{-1}\right)$ would be low due to the depleted nutrients in the water-column. During the flow release month microalgal biomass would increase. A flow of $\sim 2 \mathrm{~m}^{3} \cdot \mathrm{s}^{-1}$ in November would be insufficient to scour high salinity water at depths in the upper reaches of the estuary but would introduce some nutrients and TSS into the estuary. This would stimulate a 25 to $33 \%$ increase in phytoplankton chl $a$ and a doubling in intertidal benthic chl $a$ for a period of two months following the release. A strong halocline would develop in the upper and middle reaches of the estuary, hence subtidal benthic chl $a$ is unlikely to change significantly in these regions. From about one week after the release, diatoms would dominate the phytoplankton $(>50 \%)$ but this would not last for longer than 2 to 3 weeks before flagellates become dominant again. The effects of the freshwater on the micro-algae would only persist for $\sim 2$ months. The rest of the year would be similar to the present state.

Scenario 2 would provide for a flow release of $5 \times 10^{6} \mathrm{~m}^{3}$ from the Mpofu Dam in October and another in January would introduce nutrients and TSS into the estuary. The microalgal response would be similar to that described for Scenario 1 although biomass would increase on two occasions and there would therefore be a longer lasting effect in the estuary. There would be a $25 \%$ increase in phytoplankton chl $a$ and a doubling in intertidal benthic chl $a$ for a period of two months after both releases. The rest of the year would be similar to the present state.

For Scenario 3, the Kromme would be in its present state $\left(2 \times 10^{6} \mathrm{~m}^{3}\right.$ release $)$ and the Geelhoutboom would provide a flow $>0.08 \mathrm{~m}^{3} \mathrm{~s}^{-1}$ for a possible two months per year. The Geelhoutboom Tributary is shallow in its upper reaches and deepens towards the confluence with the Kromme. This bathymetry is 
ideal for the formation of an REI zone provided flow creates a longitudinal salinity gradient and the tributary is not flushed too quickly, i.e. flow must not exceed $1.0 \mathrm{~m}^{3} \cdot \mathrm{s}^{-1}$. However, the volume of the tributary is small relative to the Kromme so contributions to the overall system would be small. Increases in micro-algal biomass and richness would be restricted to in or near the tributary. The possible formation of a REI zone in the tributary as well as the input of nutrients and TSS from the freshwater input would increase phytoplankton chl a within the Geelhoutboom to $6-10 \mu \mathrm{g} \cdot \ell^{-1}$. The gradual increase in organic matter, fine sediment and nutrient content in the sediment of the Geelhoutboom Tributary would favour an increase in benthic micro-algal biomass. However, freshwater input is limited to two months and the overall contribution to the Kromme Estuary would be small.

Scenario 4 (flow release of $5 \times 10^{6} \mathrm{~m}^{3}$ in November) is similar to Scenario 1 as the freshwater release will create a salinity gradient in the Kromme Estuary in November. However, conditions are improved in the Geelhoutboom Tributary as it would have a salinity gradient in September, October and November. The responses would be similar to those described for Scenario 3.

Based on hydrological information, there is little difference between Scenario 5, flow release of $7.5 \times 10^{6} \mathrm{~m}^{3}$ in October and November, and Scenario 2. The only difference is that the release would be over two consecutive months with a flow of between 1 and $2 \mathrm{~m}^{3} \cdot \mathrm{s}^{-1}$, in contrast to a slightly stronger flow for two months but separated by two months in Scenario 2. There is an expected decrease in salinity in the Geelhoutboom Tributary.

A comparison of the different scenarios indicates that two months of flow release are better than one. Improving freshwater inflow to the Geelhoutboom Tributary would be beneficial to the tributary but would have little overall effect on the Kromme Estuary. The best option for improving micro-algal biomass and diversity is to increase flow to the Kromme Estuary via releases from the Mpofu Dam. The more frequent the releases the greater the opportunity for increases in micro-algal abundance and diversity.

\section{Conclusion}

River inflow has been severely decreased into the Kromme Estuary primarily due to dam construction. Flow has also been reduced into the Geelhoutboom Tributary. This has resulted in a reduction in nutrient and sediment loads entering the estuary. Phytoplankton chlorophyll $a$ has been consistently low in the estuary $\left(<10 \mu \mathrm{g} \cdot \ell^{-1}\right)$ even after a pulse of freshwater, probably as a result of low ambient nutrient concentrations and herbivory. The morphology and hydrology of the estuary are unsuitable for the formation of micro-algal blooms because the formation of strong salinity stratification and a long enough residence time is unlikely to occur. Water from the Mpofu Dam had a high ( $>50 \%$ ) relative abundance of diatoms prior to a freshwater release in 1998 (Snow et al., 2000a) and small flagellates dominate the estuary during periods of low or no flow. It is likely that a release of freshwater from the dam will introduce water that is dominated by diatoms, causing a slight shift in community composition shortly after the release. Benthic chlorophyll $a$ can reach concentrations in excess of $12 \mu \mathrm{g} \cdot \mathrm{g}^{-1}$ and this is most likely to occur in the finer sediment located in the middle reaches of the estuary and in the Geelhoutboom Tributary. Pulses of freshwater are unlikely to have an affect on subtidal benthic biomass but intertidal chlorophyll $a$, particularly in the middle to upper reaches of the estuary, should increase by up to a third follow- ing a release. This is the result of inflowing freshwater 'floating' above the denser saline water.

\section{Acknowledgements}

The Department of Water Affairs and Forestry are thanked for funding this study which formed part of the comprehensive Ecological Reserve assessment for the Kromme Estuary. Ms Rajkaran and Mrs Bezuidenhout assisted in the field. Ms Jika analysed the November 2003 samples as a component of her B.Sc. Honours degree and Mrs Smailes assisted with the phytoplankton counts. The reviewers are thanked for their valuable input.

\section{References}

AUSTEN I, ANDERSEN TJ and EDELVANG K (1999) The influence of benthic diatoms and invertebrates on the erodibility of an intertidal mudflat, the Danish Wadden Sea. Estuarine, Coast. Shelf Sci. 49 (1) 99-111.

BAIRD D and HEYMANS JJ (1996) Assessment of the ecosystem changes in response to freshwater inflow of the Kromme River Estuary, St. Francis Bay, South Africa: A network analysis approach. Water SA 22 307-318.

BATE GC and ADAMS JB (2000) The effects of a single freshwater release into the Kromme Estuary: Overview and interpretation for the future. Water SA 26 329-332.

BATE GC and HEELAS BV (1975) Studies on the nitrate nutrition of two indigenous Rhodesian grasses. J. Appl. Ecol. 12 941-952.

BICKERTON IB and PIERCE SM (1988) Estuaries of the Cape Part II: Synopses of Available Information on Individual Systems. Report No. 33 Krom (CMS 46) and Kabeljous (CMC 47), CSIR Research Report 432.

CSIR (2005) Kromme Estuary Ecological Reserve Study. Specialist Report: Hydrodynamics and Water Quality. Prepared for Coastal and Environmental Services. CSIR Stellenbosch. $80 \mathrm{pp}$.

DALSGAARD T (ed.), NIELSEN LP, BROTAS V, VIAROLI P, UNDERWOOD GJC, NEDWELL DB, SUNDBACK K, RYSGAARD S, MILES A, BARTOLI M, DONG L, THORNTON DCO, OTTOSEN LDM, CASTALDELLI G and RISGAARD-PETERSON N (2000) Protocol Handbook for NICE - Nitrogen Cycling in Estuaries: A Project under the EU Research Programme: Marine Science and Technology (MAST III). National Environmental Research Institute, Silkeborg, Denmark. 62pp.

DAWES CJ (1981) Marine Botany. John Wiley and Sons, Inc., New York. 306-309.

EMMERSON WD, WATLING HR and WATLING RJ (1982) Community Analyses in the Kromme and Swartkops Estuaries and in the Algoa Bay Region. University of Port Elizabeth. Zoology Department. Report No. 16. 128 pp.

HILMER T (1990) Factors Influencing the Estimation of Primary Productivity in Small Estuaries. Ph.D. Thesis, University of Port Elizabeth.

JERLING HJ and WOOLDRIDGE TH (1994) The mesozooplankton of a freshwater-starved estuary. In: DYER KR and ORTH (eds.) Changes in Fluxes in Estuaries: Implications from Science to Management. Olsen \& Olsen.

JEZEWSKI WA and ROBERTS CPR (1986) Estuarine and Lake Freshwater Requirements. Technical Report No. TR 129, DWA Pretoria.

MACINTYRE HL, GEIDER RJ and MILLER DC (1996) Microphytobenthos: The ecological role of the 'Secret Garden' of unvegetated, shallow-water marine habitats. 1. Distribution, abundance and primary production. Estuaries 19 186-201.

MAUSETH JD (1994) Botany: An Introduction to Plant Biology $\left(2^{\text {nd }}\right.$ edn.) Saunders College Publishing. 794 pp.

MILLER DC, GEIDER RJ and MACINTYRE HL (1996) Microphytobenthos: The ecological role of the 'Secret Garden' of unvegetated, shallow-water marine habitats. 2. Role in sediment stability and shallow-water food webs. Estuaries 19 202-212. 
NEDWELL DB, JICKELLS TD, TRIMMER $M$ and SANDERS R (1999) Nutrients in estuaries. Adv. Ecol. Res. 29 43-92.

NUSCH EA (1980) Comparison of different methods for chlorophyll and phaeopigment determination. Arch. Hydrobiol. Beiheft Ergeb. Limnol. 14 14-36.

PINCKNEY J and ZINGMARK RG (1993) Biomass and production of benthic microalgal communities in estuarine habitats. Estuaries $\mathbf{1 6}$ 887-897.

REDDERING JSV (1988) Prediction of the effects of reduced river discharge on the estuaries of the south-eastern Cape Province, South Africa. S. Afr. J. Sci. 84 726-730.

REDDERING JSV and ESTERHUYSEN K (1983) Sedimentation in the Kromme Estuary. ROSIE Report No.6, University of Port Elizabeth.

SCHARLER UM, BAIRD D and WINTER PED (1997) Diversity and Productivity of Biotic Communities in Relation to Freshwater Inputs in Three Eastern Cape Estuaries. Report to the Water Research Commission. WRC Report No. 463/1/98.
SNOW GC, BATE GC and ADAMS JB (2000a) The effects of a single freshwater release into the Kromme Estuary. 2: Micro-algal response. Water $S A 26$ 301-310.

SNOW GC, BATE GC and ADAMS JB (2000b) Effect of river flow on estuarine microalgal biomass and distribution. Estuarine Coast. Shelf Sci. 51 255-266.

SNOW GC (2000) Structure and Dynamics of Microalgae in the Gamtoos Estuary. M.Sc. Thesis. Botany Department, University of Port Elizabeth. 104 pp.

STANDARD METHODS (1989) Standard Methods for the Examination of Water and Waste Water (17 th edn.) CLESCERI E, GREENBERG AE and RHODES-TRUSSEL R (eds.) American Public Health Association (APHA). Author: This publication is not referenced in the text; please do

UNDERWOOD GJC and KROMKAMP J (1999) Primary production by phytoplankton and microphytobenthos in estuaries. Adv. Ecol. Res. 29 93-153. 